\title{
PHOTOELECTRICAL PROPERTIES OF INDANDIONE CHROMOPHORE IN SOLID STATE
}

\author{
J. Sipols, I. Muzikante, E. Fonavs \\ Institute of Solid State Physics, University of Latvia, \\ Kengaraga Street 8, Riga, LV-1063 \\ e-mail: skazis@inbox.lv
}

\begin{abstract}
The optically induced switching of electrical properties of indandione type molecules, which consist of acceptor and donor groups, are investigated. Both calculation and experimental results show a reversible highly dipolar photoinduced intramolecular electron transfer in 2-(4'-N,N-dimethylaminobenzyliden)indan-1,3dione molecule (DMABI). Kelvin's probe technique is applied to investigate the surface potential of a host-guest polymer film with four different DMABI derivatives. The derivatives have been chosen to compare the influence of the geometry, concentration and dipole moment of a molecule in the ground and excited states on the response time and amplitude of photoinduced surface potential. It is shown that the time of fast response (up to several seconds) to irradiation is independent of the concentration of molecules in a polymer film. Dependence of the amplitudes of photoinduced changes in the surface potential on the molecules concentration is observed for DMABI and its three derivatives. The optimal concentration of guest molecules in the polymer matrix is in the range 10-25 $\mathrm{wt} \%$ (depending on the molecule).
\end{abstract}

Key words: surface potential, photoinduced switching processes, indandione, host-guest polymer film.

\section{INTRODUCTION}

Switchable $\pi$-conjugated organic materials are promising in view of their potential applications in electronic and information storage devices. External light is a quick, simple, and effective stimulus to induce switching in information storage systems [1]. Organic molecules with large dipole moments contain chromophores consisting of acceptor and donor groups bridged by a delocalized $\pi$ electron system. Both calculations and experimental data show a reversible highly dipolar photoinduced intramolecular electron transfer (PIET) in indandione derivatives accompanied by change in the value of the dipole moment and in the sign $[2,3]$.

It is shown that the optically-induced switching of electric dipole moment due to PIET process is very fast, in the order of femtoseconds $[2,3]$. These molecules contain both electron-donor (D) and electron-acceptor (A) parts interconnected through a bridge $(\mathrm{D}-\mathrm{X}-\mathrm{A})$. The interaction between the lower unoccupied molecular orbital (LUMO) of the acceptor and the higher occupied molecular orbital (HOMO) of the donor part takes place, and a new absorption band characterizing PIET $\left(\lambda_{\text {PIET }}\right)$ is observed. The geometry of a molecule in the ground and excited states is almost the same; hence, no additional free volume is 
required. It is very important for a photoinduced switching process in thin polymer films with incorporated chromophores.

\section{MOLECULES}

The dipole moments of a molecule in the ground and excited states are influenced by substituents. To modify the dipole moment, and, at the same time, to optimize the properties of film formation, a number of indandione derivatives were synthesized in V. Kampar's group at the Riga Technical University. In this paper we concentrate on the photoelectrical properties of thin polymer films built of some derivatives of dimethylaminobenzylidene 1,3-indandione (DMABI) with large change of the dipole moment in the ground and excited states of the molecule, and present a method for transferring the photoinduced reaction into an electrical response. For our research we have chosen (DMABI) and its five derivatives (see Fig. 1) in polymer (PMMA) matrix - host-guest films. The influence of molecular structure and the values of dipole moments in the ground and excited states on the photoinduced switching of surface potential were investigated.<smiles>CN(C)c1ccc(C=C2C(=O)c3ccccc3C2=O)cc1</smiles>

DMABI<smiles>O=C1C(=Cc2ccc(N(c3ccccc3)c3ccccc3)cc2)C(=O)c2ccccc21</smiles>

DMABI-dPh

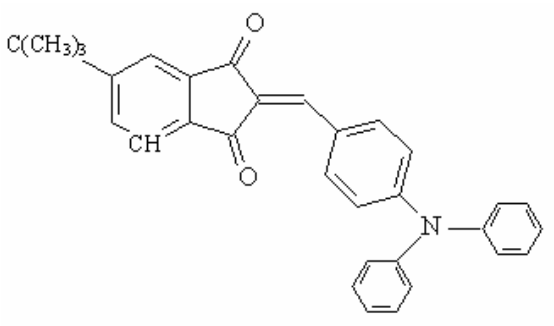

tBu-DMABI-dPh<smiles></smiles>

N-DMABI<smiles>O=C1C(=Cc2ccc(N(c3ccccc3)c3ccccc3)cc2)C(=O)c2ncccc21</smiles>

N-DMABI-dPh<smiles></smiles>

D-DMABI

Fig. 1. Dimethylaminobenzylidene 1,3-indandione (DMABI) and its derivatives.

The dipole moment values for a molecule in the ground and excited states were obtained by quantum-chemical calculations applying a semi-empirical 
ZINDO/S method of HyperChem software package. The molecular geometry was optimised by ab initio calculations with the basis set $6-31 G^{* *}$. The values of dipole moment in ground and excited states of molecules are presented in Table 1 [4]. As is shown in this table, the difference between the dipole moments in ground and excited states is $c a .10 \mathrm{D}$, which is unusually large.

Calculated dipole moments of a molecule in ground state $\mu_{g}$ and excited state $\mu_{e x} ; \alpha$ is the angle between both dipole moments; $\lambda_{\text {PIET }}$ is the wavelength of photoinduced intramolecular electron transfer of the molecule (measured in chloroform solvent).

\begin{tabular}{|l|c|c|c|c|}
\hline \multicolumn{1}{|c|}{ Molecule } & $\mu_{g}(\mathrm{D})$ & $\mu_{e x}(\mathrm{D})$ & $\cos \alpha$ & $\lambda_{\text {PIET }}(\mathrm{nm})$ \\
\hline DMABI & 2.21 & 10.94 & 0.902 & 481 \\
\hline DMABI-dPh & 1.18 & 12.24 & 0.671 & 492 \\
\hline tBu-DMABI-dPh & 1.65 & 11.73 & 0.304 & 479 \\
\hline N-DMABI & 2.08 & 10.70 & 0.760 & 502 \\
\hline N-DMABI-dPh & 4.02 & 14.55 & 0.710 & 511 \\
\hline D-DMABI & 5.55 & 14.60 & 0.908 & 557 \\
\hline
\end{tabular}

\section{SURFACE POTENTIAL}

To study electrical properties of host-guest polymer films a method involving surface potential $U_{s}$ was used. The method provides useful information regarding both structural and electronic properties of oriented films $[5,6]$. The surface potential of a film depends on both the packing density and the orientation of polar molecules. Consequently, at irradiation of a molecule the changes in the molecular dipole moment normal to the surface of the film emerge, and the changes of surface potential $U_{S}$ might be observed. The surface potential can be related to the dipole moment normal to the plane of molecular layer, $\mu_{x}$ [7]:

$$
\mu_{x}=\varepsilon \varepsilon_{0} A U_{S},
$$

where $A$ is the average area occupied by the molecule, $\varepsilon$ is the permittivity of molecules, and $\varepsilon_{0}$ is the permittivity of vacuum.

\section{EXPERIMENTAL}

\subsection{Preparation of polymer thin films}

Thin films were conceived as a host-guest system consisting of indandione type molecules (guest) and syndiotactic polymethylmetacrylate s-PMMA (host). The films were prepared by the spin-coating method. The molecules and s-PMMA were dissolved in chloroform. As chloroform is more or less quickly evaporable, this was good enough solution to use for making thin films on an indium-tin oxide (ITO) covered glass electrode in a spin-coating setup. To study the influence of molecule concentration (mass percentage $-\mathrm{wt} \%$ ) on the photoelectrical properties, samples with 1, 5, 10, 15, 20 and $25 \mathrm{wt} \%$ of applied molecules were prepared. After spin-coating the samples were left at least for a day in the air. The thickness of polymer films was measured with a surface profiler Dektak 150, and the values obtained were in the range $0.7-2.0 \mu \mathrm{m}$. 


\subsection{Orientation of polymer thin films}

The thin films, as made by spin coating, contain a randomly distributed molecular organization or amorphous structure; hence, the dipole moment and, correspondingly, the surface potential of the film are close to zero. To observe any photo-induced effect of a polar molecule due to change of the dipole moment it is necessary to orient molecules in electric field. One of the most popular methods is the corona poling [8], which in our experiments was applied at temperatures 90$120^{\circ} \mathrm{C}$ depending on the guest molecule concentration in s-PMMA. At these temperatures, which are close to glass transition temperature of host-guest film polar molecules could orient with less resistivity. The corona poling procedure lasted for $20 \mathrm{~min}$ with the corona current of $0.5 \mu \mathrm{A}$ and voltage of $3.6-9.6 \mathrm{kV}$ applied to a tungsten wire. A mask with diameter of $1 \mathrm{~cm}$ was used so that a definite region is poled. After that the sample was cooled to room temperature, while the applied electric field remained constant. Investigations of samples were carried out from 2 to 7 days after poling.

\subsection{Structural investigations of samples}

An optical microscope „Nikon Eclipse L150” was applied to investigate the morphology of host-guest films of pristine and corona poled films.

\subsection{Studies of surface potential}

Kelvin's probe (KP) method was applied as it is very common and, being non-destructive, makes it possible to rerun many times the same experiments with the same samples. Besides, it is non-contact, so the only problem was to connect the bottom (sample) ITO electrode to the electric circuit of KP device. The top plane electrode is made of gold and vibrates. As a result, we used a vibrating plane capacitor (see scheme in Fig. 2) allowing long-duration measurements of the contact potential difference. The experiments were done using home-made equipment (see [9]).

The changes of surface potential were measured as the difference between these potentials when the light is switched on and off. As the light source a light emitting diode (LED) was applied. The sample was irradiated through the bottom ITO electrode (see Fig. 2).

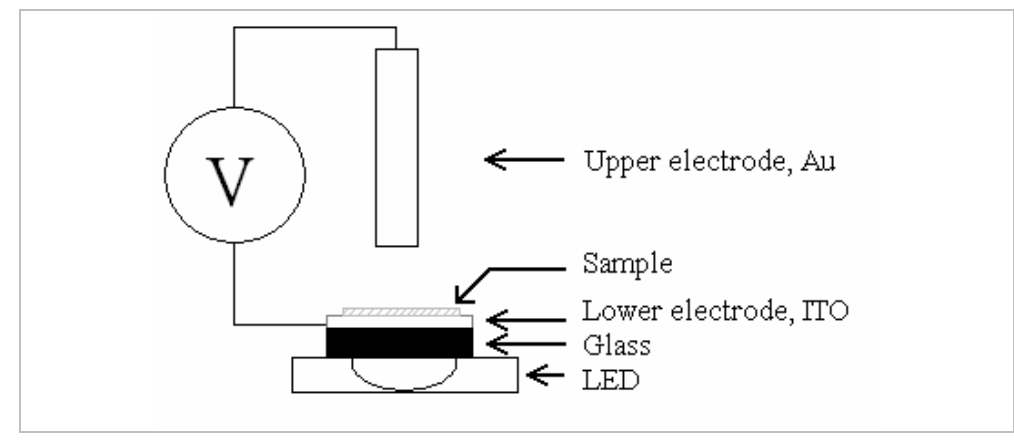

Fig. 2. Kelvin's probe scheme.

The wavelengths were chosen so that for corresponding samples they are as close to PIET region of the guest molecule as possible (see Table 1). In expe- 
riments, LEDs with wavelengths 477, 505 and $525 \mathrm{~nm}$ were applied. The light power density was within the range of $0.9-3.4 \mathrm{~mW} / \mathrm{cm}^{2}$. The measurements were made in the air at room temperature.

\section{RESULTS AND DISCUSSION}

From the optical images of host-guest films shown in Fig. 3 it follows that the polar molecules have a tendency to form crystallites in polymer matrix. It should be remembered that the interacting dipoles prefer to be oriented in the opposite directions. The probability to form crystallites appears during the corona poling. As is mentioned in the experimental part, molecules are oriented under high electric field when the sample temperature is close to glass transition temperature $T_{g}$ of the host-guest film (compare Figs. $3 a$ and $3 b$ ). In this case, the polymer matrix becomes soft, and the molecules can both orient in the direction of electric field and/or move. Besides, at higher concentration of chromophores a formation of crystallites of guest molecules after corona in the host matrix is observed [10] (compare Figs. $3 c$ and $3 e$ ). The dipole moment of the film depends on the number of free molecules and their orientation towards the substrate in polymer matrix. Due to formation of crystallites, the number of free molecules decreases. Consequently, it is important to find an optimal concentration of polar molecules when the photoinduced changes of surface potential are the greatest.

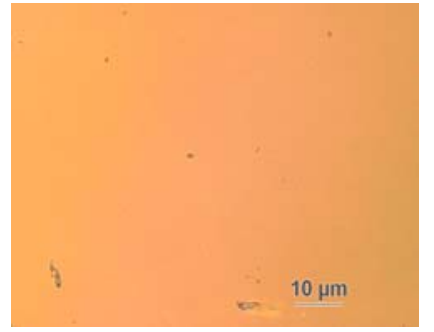

$a$

$c$

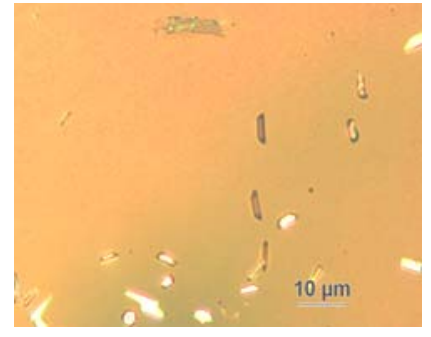

$\boldsymbol{b}$

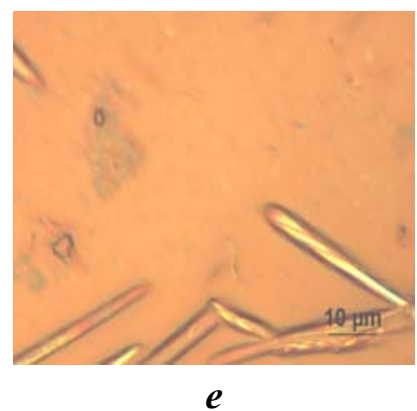

Fig. 3. Images of spin-coated pristine $(a)$ and corona poled $(b)$ DMABI/sPMMA films with $15 \mathrm{wt} \%$ concentration of DMABI molecules. Images of corona poled DDMABI/sPMMA films with $15 \mathrm{wt} \%$ (c), $20 \mathrm{wt} \%(\mathrm{~d})$, and $25 \mathrm{wt} \%$ (e) concentration of DDMABI molecules.

The photoinduced changes of the surface potential were studied in corona poled regions of the samples. Thin polymer films of all investigated DMABI derivatives undergo reversible changes of surface potential $U_{S}$ at irradiation in PIET spectral region. In Fig. 4 the change in the surface potential of host-guest DMABI- 
$\mathrm{dPh} / \mathrm{s}-\mathrm{PMMA}$ polymer films was examined for irradiation with light at $477 \mathrm{~nm}$, which corresponds to PIET. When the light is switched on, an increase in the absolute value of surface potential $U_{S}$ is observed. The surface potential returns to the initial value when irradiation is switched off.

The dependence of $U_{S}$ on the irradiation time may be well fitted by the two exponential functions:

$$
U_{S}(t)=A \exp \left(-t / \tau_{A}\right)+B \exp \left(-t / \tau_{B}\right),
$$

where $A, B$ are the amplitudes, and $\tau_{A}, \tau_{B}$ are time constants characterizing the response of the process to irradiation. The response time and amplitudes were the same after several repeated cycles of irradiation.

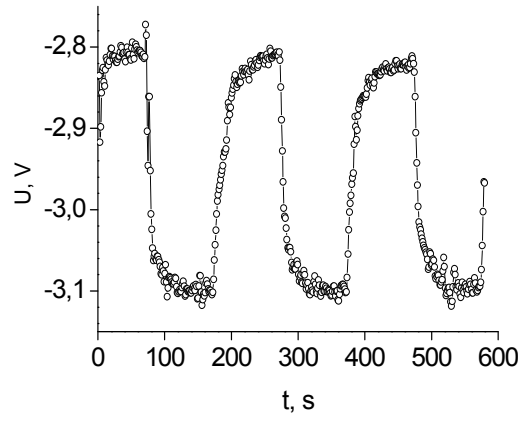

Fig. 4. Photoinduced changes of surface potential of DMABI-dPh/sPPMA film. The concentration of DMABI-dPh molecules $10 \mathrm{wt} \%$.

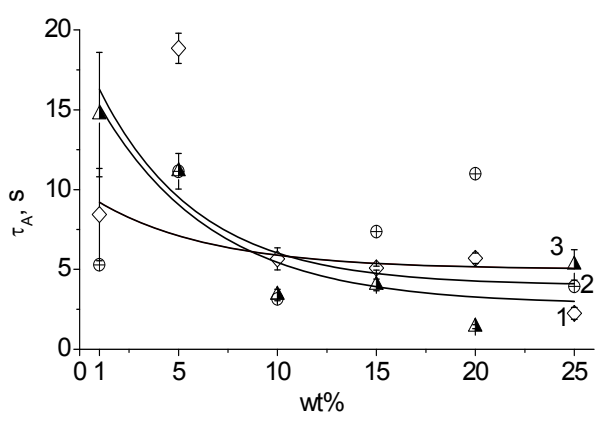

Fig. 5. Dependence of response time $\tau_{A}$ on concentration of DMABI (1), DMABI-dPh (2) and tBu-DMABI-dPh (3) in sPPMA matrix.

The presence of two exponential functions may be caused by at least two processes in a host-guest film during irradiation. The initial faster response was in the order of several seconds, while the slower response lasted several minutes. According to the studies into the decay of nonlinear optical properties [11], the initial faster decay of the surface potential can be related to the rotation of polar molecules in the polymer matrix. The slower response may be due to reorganisation of molecular order caused by the interaction between polar molecules in the polymer matrix and the interaction between these polar molecules and polar groups of polymer. The fast response time $\tau$ (see Fig. 5) practically does not change with increasing concentration up to $25 \mathrm{wt} \%$ of polar molecules.

The amplitudes characterizing fast response of the surface potential to irradiation in dependence on the molecules concentration are presented in Fig. 6 for DMABI and its derivatives. The dependence of the photoinduced changes in surface potential on the molecules concentration was observed almost in all cases except N-DMABI and N-DMABI-dPh molecules. As seen in Fig. 6 (curves 4 and 5 ), the amplitude values for these samples are smaller in comparison with those of other derivatives, while no evident relation with molecules concentration is observed. In the case of DMABI and tBu-DMABI-dPh a tendency towards saturation of the amplitude value is expected at concentrations higher than $20 \mathrm{wt} \%$. At the same time, in polymer films with DMABI-dPh and DDMABI molecules the 
optimal concentration of guest molecules was observed. In DMABI-dPh/s-PMMA films at concentration of $15 \mathrm{wt} \%$ the highest value for the fast process amplitude $A$ (of $403 \pm 7 \mathrm{mV}$ ) was obtained (see Fig. 6, curve 2). In DDMABI/s-PMMA films the maximum value of the fast process amplitude of $465 \pm 15 \mathrm{mV}$ is reached already at $10 \mathrm{wt} \%$. To analyze the correlation between the dipole moments of the molecules and photoinduced properties of the surface potential of films, the difference between these dipole moments for the excited and ground states as well as photoinduced response time and amplitude values were considered.
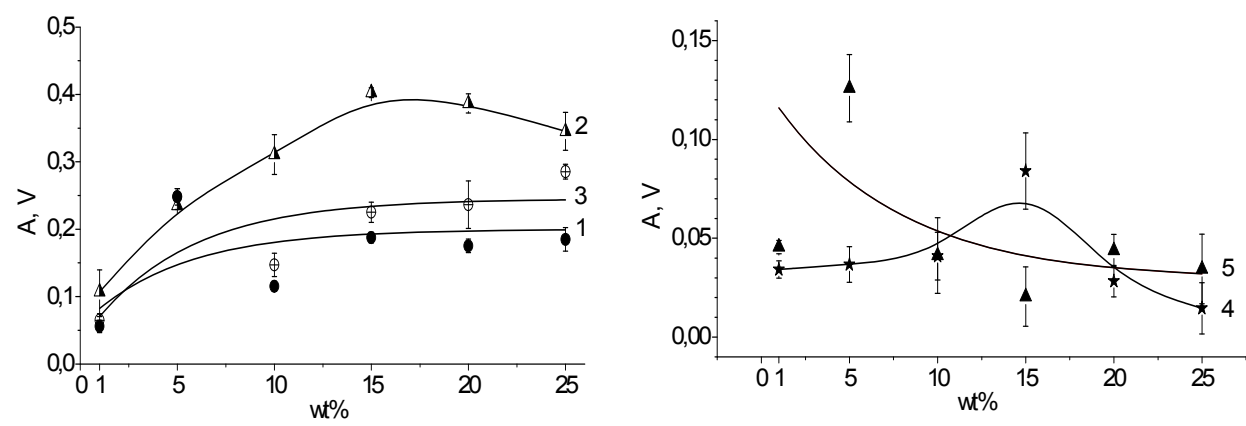

Fig. 6. Concentration dependence of amplitudes characterizing fast response of the surface potential to irradiation for DMABI (1), DMABI-dPh (2), tBu-DMABI-dPh (3), N-DMABI (4) and $\mathrm{N}-\mathrm{DMABI}-\mathrm{dPh}(5)$ molecules in PMMA matrix.

The difference between the dipole moments of molecules in the excited and ground states, $\Delta \mu$, was calculated as:

$$
\Delta \mu=\mu_{g}-\mu_{e x} \cos \alpha,
$$

where $\mu_{g}, \mu_{e x}$ are the dipole moments of a molecule in the ground and excited states, respectively, and $\alpha$ is the angle between both the dipole moments.

The calculated largest $\Delta \mu$ values (in the order of $7.7 \mathrm{D}$ ) have also been obtained for DMABI and DDMABI molecules. On the contrary, the smaller values both of $\Delta \mu$ and amplitude $A$ - were obtained for N-DMABI and N-DMABI-dPh Exception is tBu-DMABI-dPh, with the smallest value of $\Delta \mu$ and comparatively large value of amplitude $A$. To explain this effect further experiments are provided.

\section{CONCLUSIONS}

Reversible switching of the surface potential of polymer films with incorporated DMABI molecules and its derivatives is observed at irradiation in the spectral region of photoinduced intramolecular electron transfer. The main advantage from the viewpoint of photoinduced switching effect is the fact that in the excited state a molecule does not change its geometry, so in the thin films no additional free volume is required.

The time of fast response (about several seconds) to irradiation is almost independent of the molecules concentration in polymer films. Dependence of amplitudes of photoinduced changes in the surface potential on the molecules concentration is observed for DMABI and its three of the five studied derivatives: DMABI-dPh, tBu-DMABI-dPh and DDMABI. The optimal concentration of guest 
molecules in the polymer matrix is in the range $10-25 \mathrm{wt} \%$ (depending on a molecule).

\title{
ACKNOWLEDGEMENTS
}

This work was supported by National Research Programme in Materials Science of Latvia.

We thank Valdis Kampars and Pauls Pastors for synthesis of DMABI and its derivatives as well as Elina Laizane for fabrication of host-guest polymer films.

\section{REFERENCES}

1. Physics of Organic Semiconductors (2005). Eds. By W.Brütting, Weinheim: WileyVCH, p.536.

2. Silinsh, E.A. (1997). SPIE Proceedings, 2968, 2-12

3. Neilands, O., \& Utinans, M. (1997). SPIE Proceedings, 296, 13-18.

4. Rutkis, M.A., Vembris, A., Zauls, V., Tokmakovs, A., Fonavs, E., Jurgis, A., \& Kampars, V. (2006). SPIE Proceedings, $61926192 \mathrm{Q}$.

5. Muzikante, I., Fonavs, E., Stiller, B., \& Brehmer, L. (2005). Advances in Colloid and Interface Science 116 133-141.

6. Iwamoto, M.(2004). Macromol. Symp. 212 39-50

7. Oliveira, O.N.Jr., Taylor, D.M., Lewis, T.J., Salvagno, S., \& Stirling, C.J.M. (1989). J.Chem.Soc. Faraday Trans. I, 8, 1009-1014.

8. Mortazavi, M.A., Knoesen, A., Kowel, S.T., Higgins, B.G., \& Dienes, A. (1989). J. Opt. Soc. Am. B, 6733-741.

9. Vilitis, O., Fonavs, E., \& Muzikante, I. (2001). Latv. J. Phys. Tech. Sci., 5 38-56.

10. Muzikante, I., Cepite, D., Fonavs, E., Tokmakov, A., Erts, D., \& Polakov, B.(2003) Latv. J. Phys. Tech. Sci., 3 49-55.

11. Suzuki, A., \& Matsuoka, Y.(1995). J. Appl. Phys., 77 965-968.

\section{INDANDIONA ATVASINĀJUMU FOTOELEKTRISKĀS ĪPAŠĪBAS CIETĀ STĀVOKLI}

\author{
J. Sīpols, I. Muzikante, E. Fonavs \\ Kopsavilku m s
}

Optiski ierosināta elektrisko īpašību pārslēgšanās (arī atgriezeniska) var tikt izmantota, lai pētītu fotoelektriskās īpašības polimēru matricās. Pētîtās indandiona molekulas sastāv no akceptora un donora grupām, kas savietotas ar delokalizētu $\pi$ elektronu sistēmu. Gan aprēķini, gan eksperimenti parāda augsti atgriezenisku fotoierosinātu iekšmolekulāro elektronu pārnesi (PIET) 2-(4'-N,N-dimethylaminobenzyliden)indan-1,3-dione molekulā (DMABI). Kelvina zondes metode tika izmantota, lai pētîtu elektriskās īpašības saimnieks-viesis polimēra matricās ar 5 dažādiem DMABI atvasinājumiem. Atvasinājumi tika izvēlēti, lai varētu salīdzināt geometrijas un dipolu momentu (ierosinātu un neierosinātu PIET reǵionā) ietekmi uz reakcijas laiku un fotoierosināto virsmas potenciālu. Reakcijas laika ātrā komponente ir ar dažu sekunžu kārtu un nemainās līdz ar molekulu koncentrācijas maiņu robežās no 1 līdz 25 sv.\%. Tai pat laikā fotoierosinātā virsmas potenciāla izmaiņas ir atkarīgas gan no molekulu struktūras, gan molekulu koncentrācijas. DMABI un 3 tā atvasinājumiem. Optimālā molekulu koncentrācija ir robežās no 10 līdz 15 sv.\%. 